\title{
ENVIRONMENTAL ASSESSMENT OF AN ABANDONED BRIQUETTE FACTORY - A CASE STUDY AT NAGYMÁNYOK AREA, FORMER INDUSTRIAL ZONE
}

\author{
Amade Halász, József Dezső, Viktoria Poor \\ Department of Geology and Meteorology, University of Pécs, Hungary
}

Manuscript received: June 27, 2015

Revised version: February 23, 2016

Halász A., Dezsó J., Poor V., 2016. Environmental assessment of an abandoned briquette factory - a case study at Nagymányok area, former industrial zone. Quaestiones Geographicae 35(1), Bogucki Wydawnictwo Naukowe, Poznań, pp. 69-79, 9 figs, 3 tables.

\begin{abstract}
The study is focused on environmental assessments of impacts by former briquette factory at the Nagymányok area in South Hungary. The (former) industrial zone is located in a northern valley of the Eastern Mecsek Mountains. Until the 1990s this company was the largest briquette factory in Hungary and the demolition works are still incomplete. Former investigations were based on only five samples. Our sampling sites were selected on the basis of the source of the contaminations and then we covered the whole area in equal distribution. We used the A1-F6 codes for the sample places. We have started from southwest to northeast. The samples were analyzed for Total Petrol Hydrocarbons (TPHs), Polycyclic Aromatic Hydrocarbons (PAHs) and for heavy metals. The area was heavily contaminated by TPHs and moderately heavy metals (such as $\mathrm{Cu}, \mathrm{Cr}, \mathrm{Zn}$ and $\mathrm{Pb}$ ). Highest contaminant concentrations were found around the former industrial buildings, especially between the boiler-house and the coal-pillbox. In the industrial area the mean of the detected values is below the upper limit of the legal exposure values, but among the former industrial buildings higher (e.g. toxic level) concentration values were detected in multiple samples. Based on our investigation the pollutant can be transported by wind or by water on the surface (stream bed) or underground. The hazardous material can easily reach some part of the city, therefore reclamation is necesarry.
\end{abstract}

KEYWORDS: Nagymányok, environmental assessment, industrial zone, metal contamination, risk characterisation

Corresponding author: Amade Halász (amadehalasz@gmail.com)

\section{Introduction}

Total Petrol Hydrocarbons (TPHs) and Polycyclic Aromatic Hydrocarbons (PAHs) and to a lesser degree by heavy metals $(\mathrm{Co}, \mathrm{Pb}, \mathrm{As}$, $\mathrm{Zu}, \mathrm{Cr}, \mathrm{Ni}$, etc.) contamination affects several areas in Hungary due to long term coal mining and briquette factories operating (Dura 2003).

The (former) industrial zone is located in a northern valley of the Eastern Mecsek Mountains (Southern Hungary). Until the 1990s this company was the largest briquette factory in Hungary, where the coal powder was cemented by bitumen.

Until today (2015), the demolition works are still incomplete; the remnants of a demolished buildings (bricks and concrete fragments) and non-demolished concretes are left lying around the area. During the investigation we found at least four buildings and their environments are highly contaminated by the different kinds of hydrocarbons: the transformer station, the bitumen 
tank, the mazout pumpstation, and the engine shed. Former investigation (Ökoproject Report 2008) concluded that the area is highly contaminated by hidrocarbons and slightly by heavy metals.

The first aim of this investigation is the identification and the routing of the pollution sources as well as to evaluate the amount of the toxic elements in the soils. Therefore we have created cross section along the areas. One of the main investigation areas is the factory itself, and the other is the railway loading territory. The second aim was to predict the ecological Risk Characterisation Ratio, and count the amount of the contaminated material (soil, sediments).

\section{The Investigated Area}

Nagymányok is located in the East Mecsek Mountains near the East Mecsek Protected Area. The investigated area was divided into two parts. On of them was the former industrial zone where the demolished briquette factory can be found and the other is the loading area close to the city. The abandoned industrial zone (Fig. 1) situated in a valley close to the city, which connect to the loading area by a dismantled railway line and parallel to a small creek flows into the Völgység stream. The valley is open to the north so the general wind direction transports the dust to the nearby vineyards and partly to the city. The two areas are divided by the Völgység stream, so the contaminant can reach it from both ways. The surface water flows to the north from the valley, so the contaminaítion routes can be easly defined, but the underground water can spread in many ways. To understand the underground water flows it is necessary to clarify the geological situation.

Three different formation can be found in the investigated area (Fig. 2). Two of them can be studied on the surface. South from the industrial zone in the valley, the Misina Group is cropping out. The lower anisian thinly bedded greyish dolomitic limestone and marl, sometimes limestone with nodules. The younger pannonian s.l. sediments are mainly yellow limonitic (pebbly) sand. Different grain size in the sand and between this layers marl, clayey marl can be found. The fauna remnants does not influence strongly the permeability. The Mecsek Coal Formation is cropping out, but more than a $\mathrm{km}$ away from the investigated area. There are two reverse fault inside the anisian limestone. The boundary between the anisian limestone and the lias sediments (consisting the coal seams) is a normalt fault.

\section{Material and Methods}

During the first field work we have found that at least four buildings and their environments are highly contaminated by different kinds of hydrocarbons: the transformer station, the bitumen tank, the mazout pumpstation, and the engine shed (Fig. 3). Therefore the number of sample were increased with some trial pit. All together more than forty samples were analyzed. Beside of our samples we have used five more historical samples data from 2008 measured by Ökoproject $\mathrm{Kft}$. However those samples has only TPH and PAH datas.

For analytical purposes the majority of the solid samples were obtained from the surface (10-30 $\mathrm{cm}$ ). Additional three test pits (to a maximum depth of $100 \mathrm{~cm}$ ) were dug by an excavator. The location of the samples and the test pits were influenced by the extension of the concrete-covered surfaces; consequently the regular net-pattern sampling system was impractical and non-feasible. Some historical samples originated from shallow boreholes near the train loading area.

Major parts of the solid samples were mixed material containing coal powder, loamy deposits, sand, gravel and soils. We have used WTW 315 with combine electrode and Radelkis, using Metrohm electrode for $\mathrm{pH}$ and electrical conductivity measurements. The quantitative TPH values were detected by PetroFlag test (US EPA Method 8015), the qualitative values by GC-MS and later we determined the "fingerprint" of the hydrocarbons by using Ocean Optics Raman spectroscope. The sample preparation and the measurements methods were based on the MSZ EN ISO 9377-2 Hungarian standard. Finally the metal contamination was measured by Niton XL3t 600 XRF Analyser.

The GC-MS, the GC-MS device Agilent 6890N gas chromatograph (GC) and 5975 mass spectrometer (MS) for a qualitative analysis were 

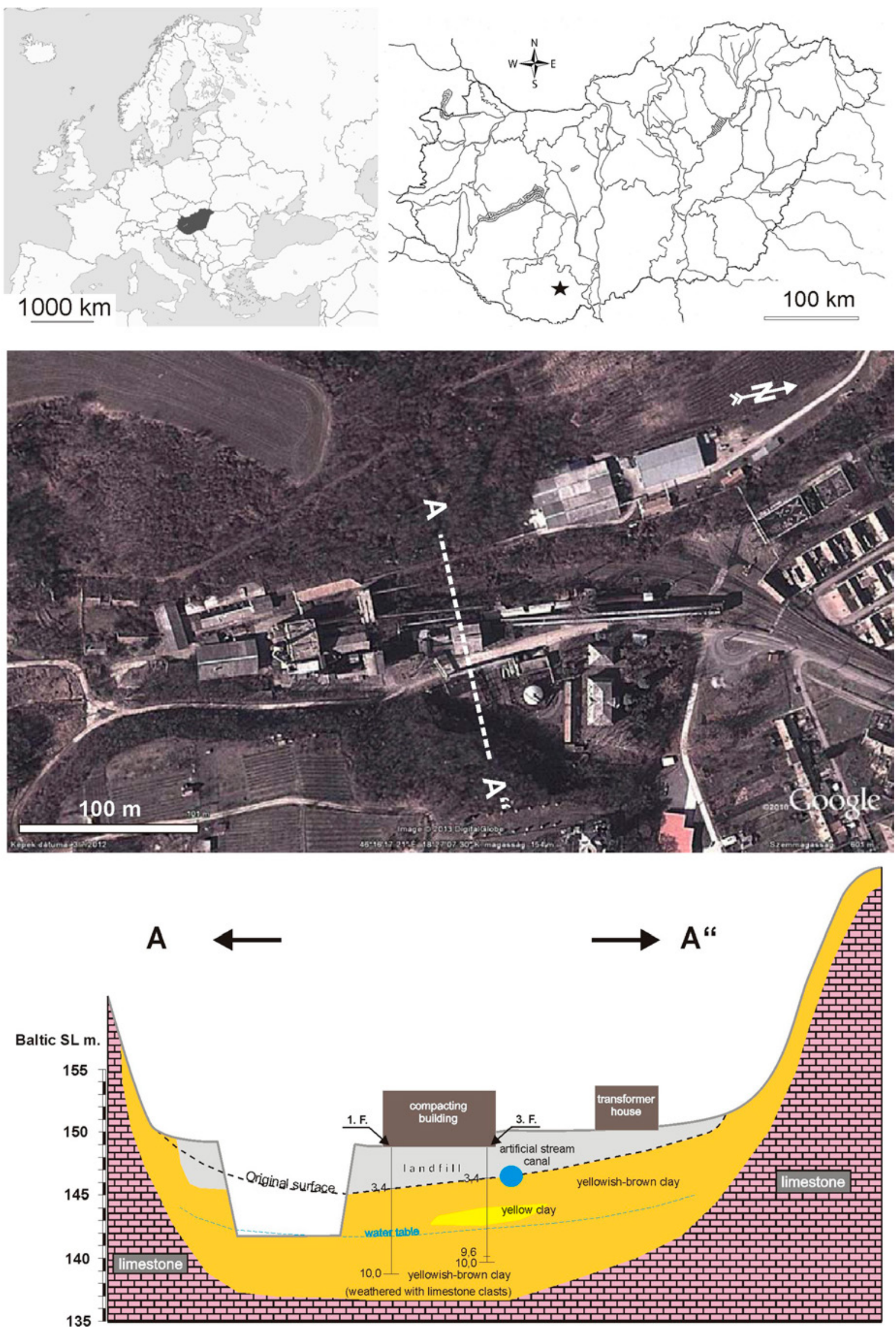

Fig. 1. The former industrial zone (briquette manufactory) and its surrounding before the demolition works. 
carried out for total petrol hydrocarbon $(\mathrm{TPH})$ measurement according to the ISO 16703:2004 standard. After the sample preparation process $1 \mu \mathrm{l}$ sample was injected in split mode (split ratio 1:15) with an automatic sampler. The injector temperature was $300^{\circ} \mathrm{C}$. The temperature for GC oven was initially set at $50^{\circ} \mathrm{C}$ for $3 \mathrm{~min}$, than ramped to $300^{\circ} \mathrm{C}$ at $10^{\circ} \mathrm{C} \mathrm{min}{ }^{-1}$ and held for 25 $\mathrm{min}$. The separation was achieved on a HP- $1 \mathrm{~ms}$ capillary column $(25 \mathrm{~m} \times 0.2 \mathrm{~mm}$ i.d. $\times 0.33 \mu \mathrm{m}$ film thickness). The flow rate of the carrier gas (helium) was $1.5 \mathrm{ml} \mathrm{min}^{-1}$. The analysis were carried out in scan mode. The MS source temperature and quadruple temperature was $230^{\circ} \mathrm{C}$ and $150^{\circ} \mathrm{C}$, respectively. The electron ionisation mass spectra were recorded at $70 \mathrm{eV}$. Hydrocarbon standards (C8-C14), diesel oil and mazut samples were used for qualitative analysis.

The Ocean Optics Raman spectrometer was used to determine a "fingerprint" of the

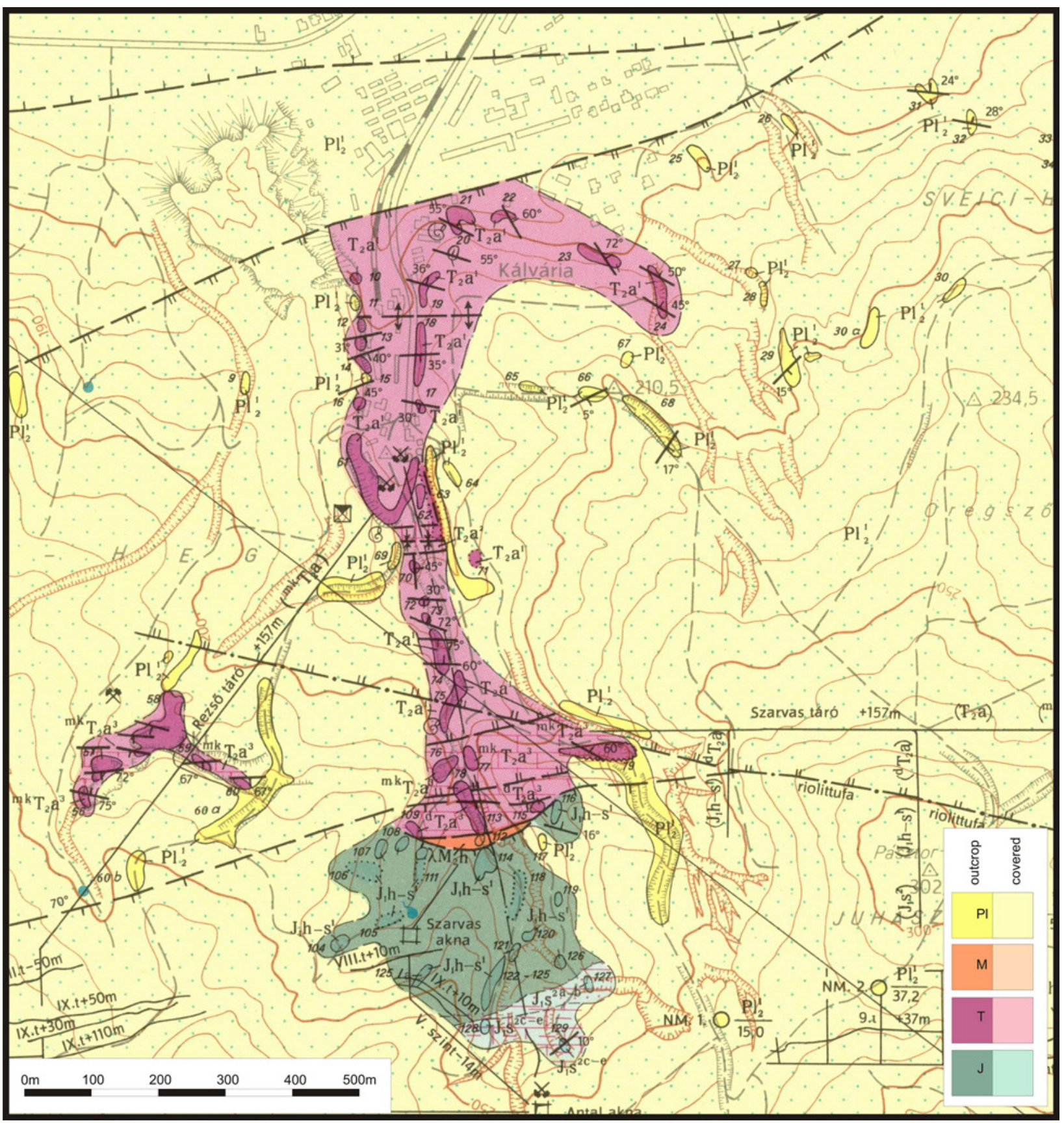

Fig. 2. Geological map of Nagymányok area (Hámor et al. 1966). Legend: $\mathrm{Pl}_{2}{ }^{1}-$ limonitic sand and sandtone; $\mathrm{M}$ - miocene rhyolite tuff; T - generally anisian dolomitic limestone, limestone; J - jurassic coal and (clayey) marl. 

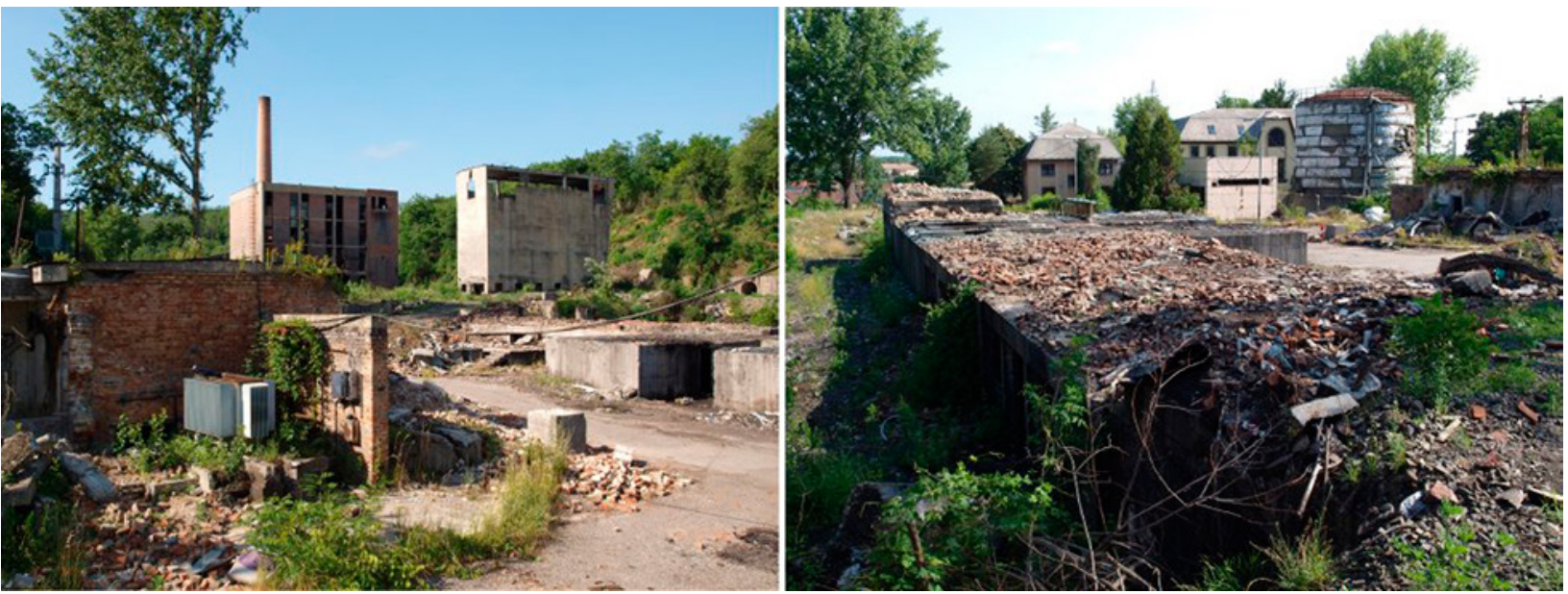

Fig. 3. Left: Transformator station (in front), the boiler-house and the coal-pillbox (background); right: demolited coal-press (in front) and the bitumen tank.

hydrocarbon contamination, inital contamination types and background. Raman spectroscopy (using $785 \mathrm{~nm}$ 200-450 mW output laser source) was used at 200-400 ms integration time. Raman spectra were collected direct from surface of the sample and by sampling through the walls of the glass vials. For the evaluation and classification of the explanation of the Raman peaks we revised from the literature; the obtained peaks demonstrate different kind of basic hydrocarbon groups).

The metal contaminations were detected by Thermo Scientific Niton XL3t 600 X-ray fluorescence Analyser $(50 \mathrm{KV} / 100 \mu \mathrm{A}$, Au X-ray source integration time: $600 \mathrm{sec}$ ).

The contaminant distribution maps were drawn by Surfer 10 software, and we used the kriging for gridding method. The statistical analysis were performed by ORIGIN Pro8 software (cross correlation, smoothing FFT method) and PAST version $2.17 \mathrm{c}$ (cluster analysis) software.

Evaluating Raman wavelenghts if the signal had high-frequency noise, the Fast Fourier Transform (FFT) filtering method were used (Origin Pro8). A FFT filter performs filtering by using Fourier transforms to analyze the frequency components in the input signal. With the cutoff frequency, the filter removes all the high-frequency noise, leaving the true signal.

Before the laboratory and field measurements we have calibrated the instruments and validated the analytical methods, also determined the errors of the process. According to Wright and Jermstad (1995) and Wright (1995) results we calibrated the PetroFLAG system with laboratory methods and the correlation were close to their results $88 \%$ and $93 \%$ respectively. One of the important factors affecting laboratory analysis is the inhomogeneous nature of soil samples. To define the determination limits and the uncertainty of the analytical process for XRF measurement the $\mathrm{SiO}_{2}$ standard matrix method were used with 120 sec calibration time (Table 1). The errors (based on our meuserements) felt into the same range as it was described by the manufacturer Niton. For the laboratory calibration of the Raman we used the Sigma Aldrich Total Petroleum Hydrocarbon Mixture 3 analytical standard. Our measurements and the official ones (AIST) shows 0.92 correlation ratio in the $1000-3000 \mathrm{~cm}^{-1}$ range.

Table 1. XRF measurement errors.

\begin{tabular}{|c|c|c|c|c|c|c|c|}
\hline $\begin{array}{c}\text { Con- } \\
\text { tami- } \\
\text { nants }\end{array}$ & $\mathrm{Cr}$ & $\mathrm{Co}$ & $\mathrm{Ni}$ & $\mathrm{Cu}$ & $\mathrm{Zn}$ & $\mathrm{As}$ & $\mathrm{Pb}$ \\
\hline $\begin{array}{c}\text { Limit } \\
\text { value } \\
\text { (ppm) }\end{array}$ & 75 & 30 & 40 & 75 & 200 & 15 & 100 \\
\hline $\begin{array}{c}\text { Error } \\
* *\end{array}$ & 8.428 & 12.94 & 25.00 & 10.74 & 5.00 & 2.88 & 4.15 \\
\hline
\end{tabular}

Based on our own data

* followed the 6/2009. (IV. 14.) KvvM-EüM-FVM Hungarian regulation

** Using $\mathrm{SiO}_{2}$ standard matrix. Calibration time: 120 seconds.

\section{Results and Discussions}

The samples were collected from the vicinity of the production buildings, contain coal (residues of the industrial process), degraded soil-types 
(rendzinas, young fluvial soils), sand and gravel particles. Around the buildings and the railways the samples contain mainly or entirely coal.

During our research we have carried out some important statistical analysis, to check our results. In the first step the normality test was carried out by using Shapiro-Wilk normality test. This type of test is less sensitive to smaller (below 50) sample size, however the results show that three of metal has normal distribution. The $\mathrm{Cr}$, $\mathrm{Co}$ and the $\mathrm{Ni}$ at the 0.05 level, the data was significantly drawn from a normally distributed population, while the others not. Therefore non-parametric tests were used subsequently. We have also carried out a Pearson rank correlation using Origin Pro8 for the heavy metal contamination types and $\mathrm{TPH}$. But it shows no correlation (0.85), because the distribution of the used substances around the industrial zone (that caused pollution) was not typical. The cluster analysis (we used Ward's method PAST version $2.17 \mathrm{c}$ ) is intended for all types of contaminants, taking into account the definition of the most contaminated group. The third group (Fig. 4) of three levels of hierarchy (distance at 2400) can be separated, which primarily determined by the amount of TPH. The outlier measured sample C4 is quite separate from the group members, but still cannot generate new (a sectional) group. This indicates that the severity of the contamination determined by
TPH basically. The third group, it can be appreciate that all the heavy metals and in terms of TPH remediation are important, particularly soiled areas are not necessarily linked designates.

The TPH values clearly indicate that they are present in a relatively high concentration in the studied area with a more profoundly contaminated center. Majority of the samples indicates that the contamination is likely of heavy hydrocarbon-types origin. The hydrocarbons are typically washed into the deeper levels. Each component (the lower-chain) can be easily mobilized, but PAHs bind strongly to the solid particles. Both level shows high average, above the official limit (Fig. 5).

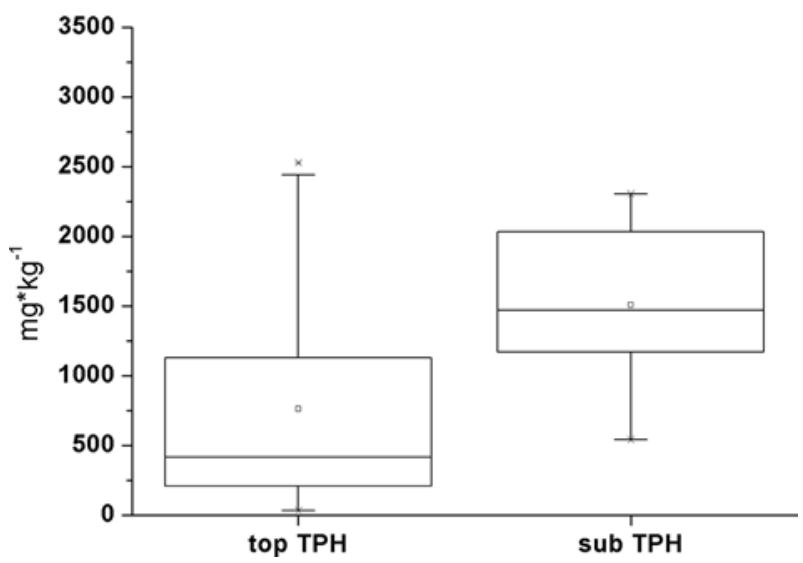

Fig. 5. Concentration of TPH in the subsurface and in the topsoil.

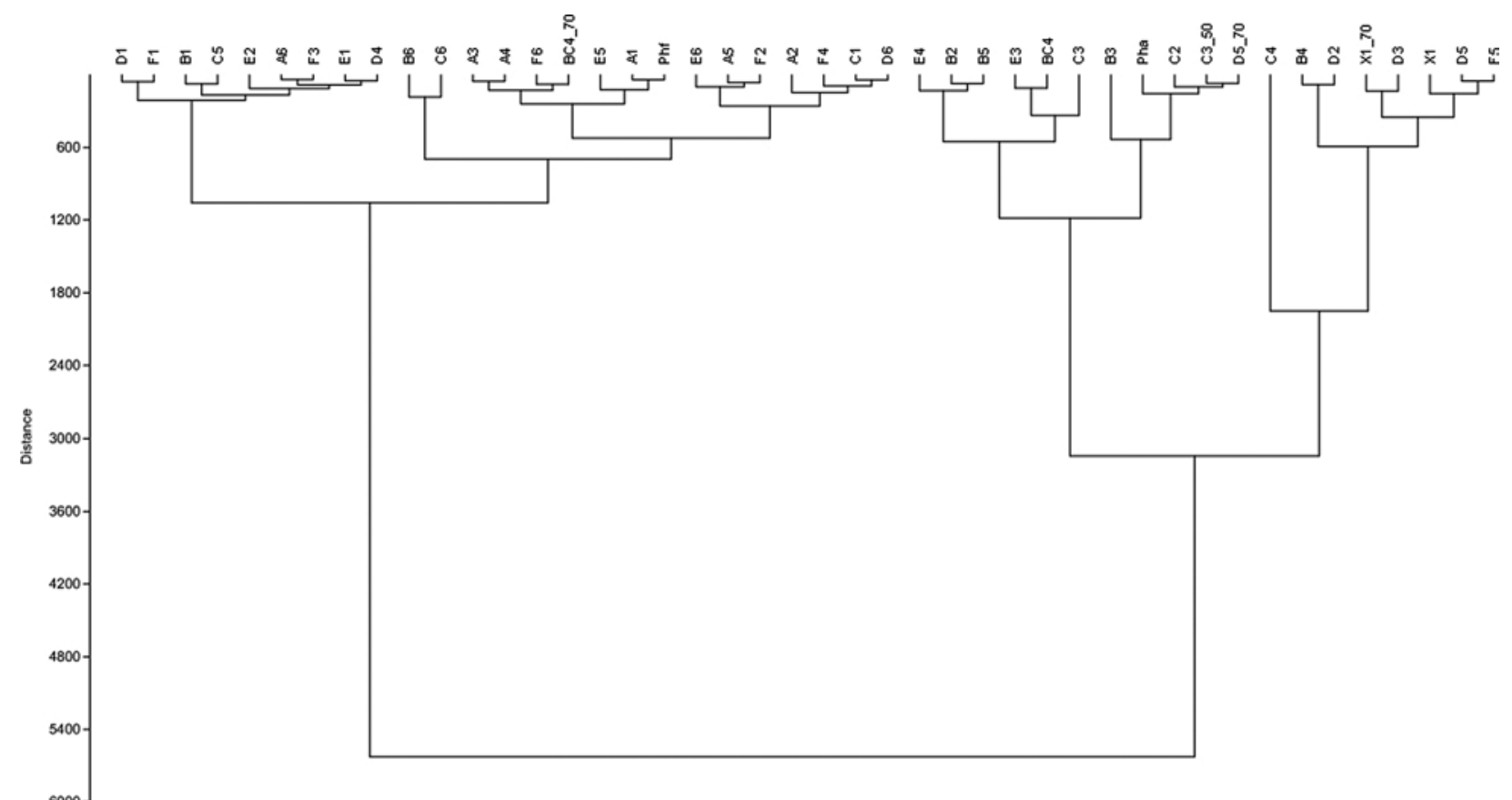

Fig. 4. Cluster analysis for the contaminant (using Ward's method PAST version 2.17c). 


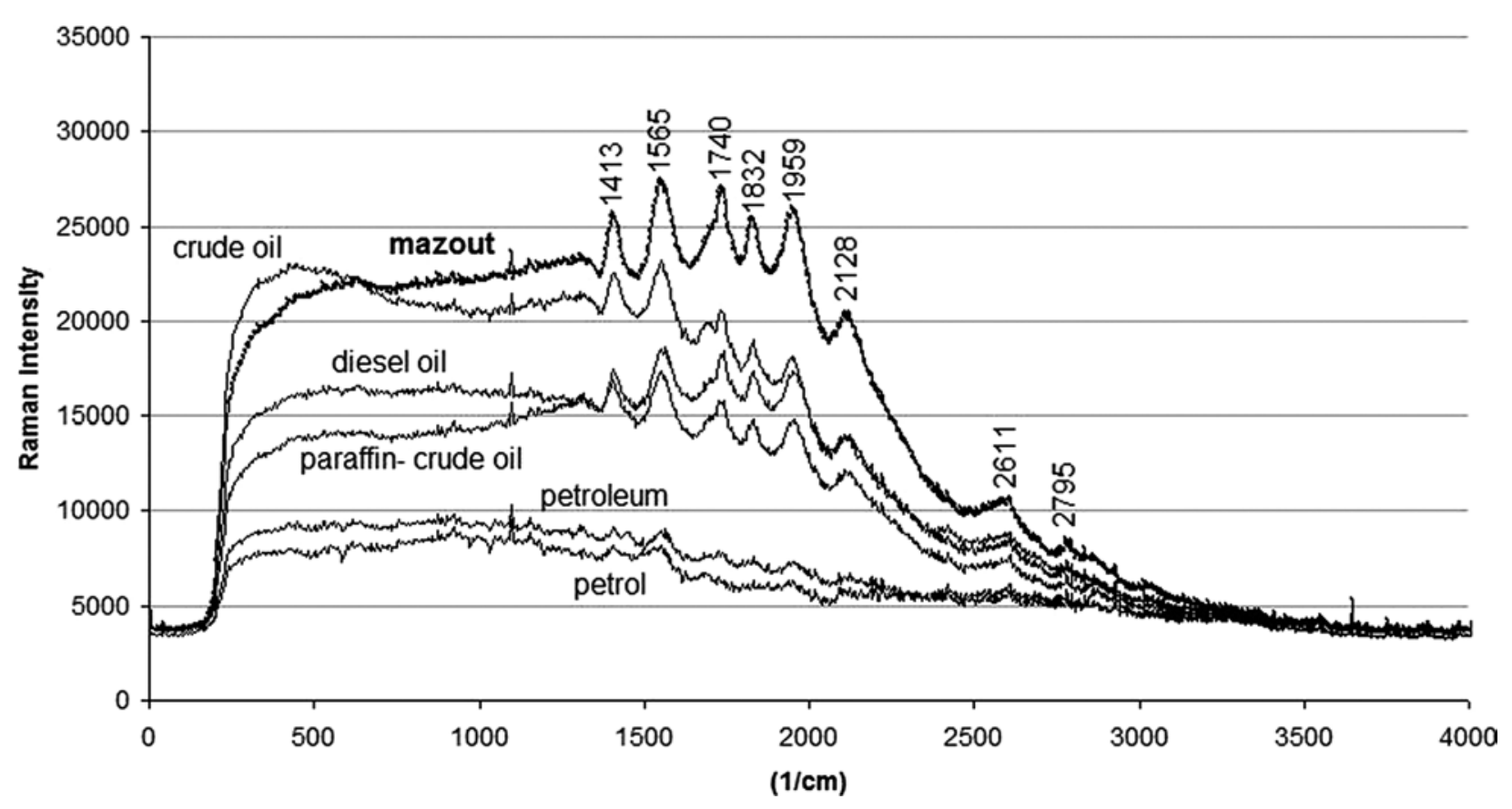

Fig. 6. The Raman shifts of the initial contamination types.

During the rapid screening test, the SERS method results a reliable "fingerprint", if we compare the native pollutant material with the collected solid samples. Therefore we measured some hydrocarbon types derived from the investigated area (Fig. 6). We have found similarities between the patterns and types of contamination, those samples are contaminated by petroleum (hydrocarbons).

The following metals as potential contaminants involving health issues felt into the detectable ranges: mainly $\mathrm{Cr}, \mathrm{Cu}, \mathrm{Zn}$, partly $\mathrm{Co}, \mathrm{Ni}, \mathrm{As}$ and $\mathrm{Pb}$. The most frequently contaminant is $\mathrm{Cr}$, but this metal has less wide interquartile range than Zinc, which has an extraordinarily wide range. The spatial distributions of the most important contaminants are visualized below (Fig. 7).

We have also carried out a risk characterisation process following a series of steps (Tarazona and Vega 2002). The aim of the of a risk assessment is to compare the estimated exposure with the estimated effects; for the environment, this is expressed as a PEC/PNEC, based on the ratio of predicted environmental concentration (PEC) and predicted no effect level (PNEC). The ratio between PEC and PNEC is ultimately used as an indicator of risk, allowing it to be quantitatively labelled. If the PEC is greater than the PNEC (ie. ratio $>1$ ), then it can be assumed that there is a risk of effects to the environment. The scale of the risk can therefore be crudely measured by considering this ratio. The Predicted Non Effect Concentration (PNEC) is based on environmental effect data and the Predicted Effect Concentration is based on models for degradation or distribution of the substance in the environment.

For the calculation of the PNEC values the ARCHE (Assessing Risks of Chemicals vers 2014 Gent Belgium) were used. The applied speardsheet calculates the predicted ecological risks of metals in soils (the widely used Risk Characterisation Ratio) based on their PNEC (Table 2). Basically the RCR=PEC/PNEC ratio.

The calculations are based on the EU REACH (Registration, Evaluation, Authorisation and Restriction of Chemicals, EC No 1907/2006) directive. The PNEC values derived from the EU REACH database; based on reliable chronic toxicity data for terrestrial organism. The method based on statistical extrapolation of the scientific results. The PNEC values are calculated for different levels of refinement such as the availability

Table 2. RCR is used as an indicator of risk.

\begin{tabular}{|c|c|}
\hline RCR & Description \\
\hline$<1$ & no immediate concern \\
\hline $1-10$ & high risk \\
\hline $10-100$ & further data required \\
\hline$>100$ & reduce risk immediately \\
\hline
\end{tabular}

After Whitehouse, Cartwright 1998. 


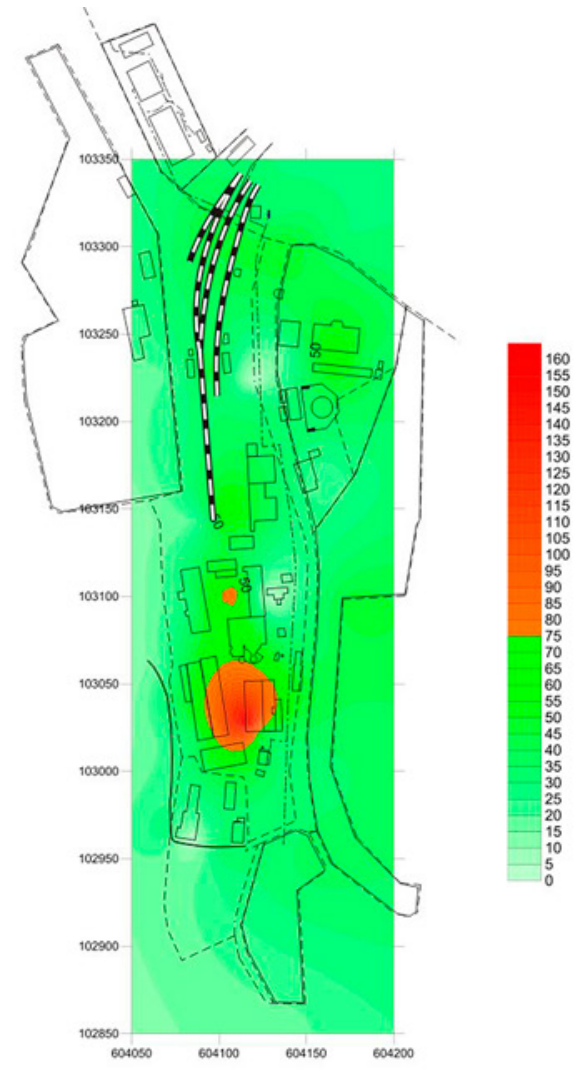

Distribution of cobalt $(\mathrm{Cu})$ in the topsoil $(\mathrm{ppm})$

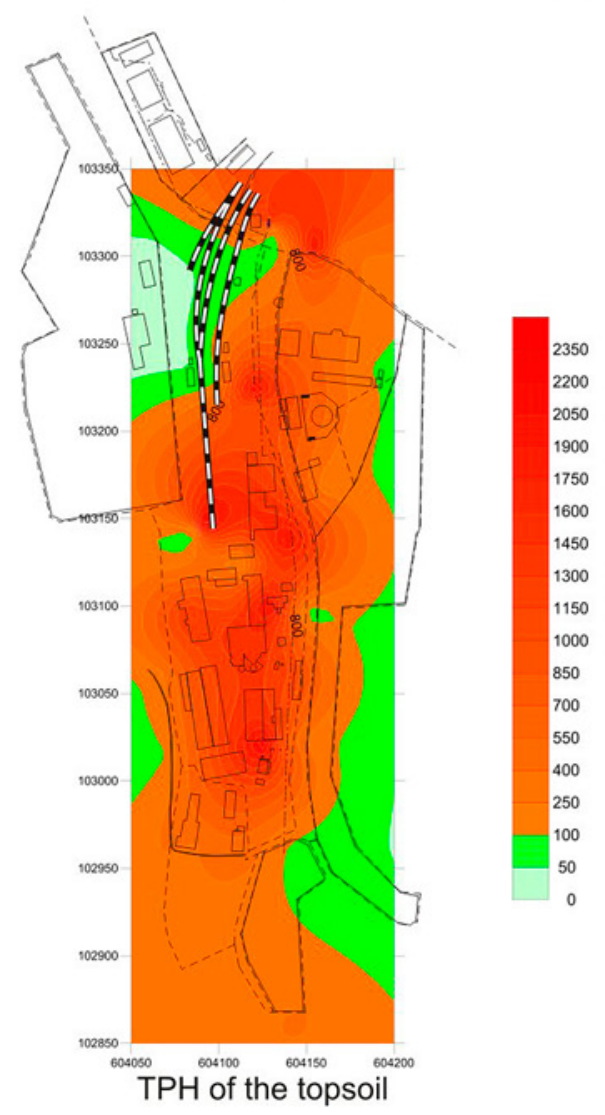

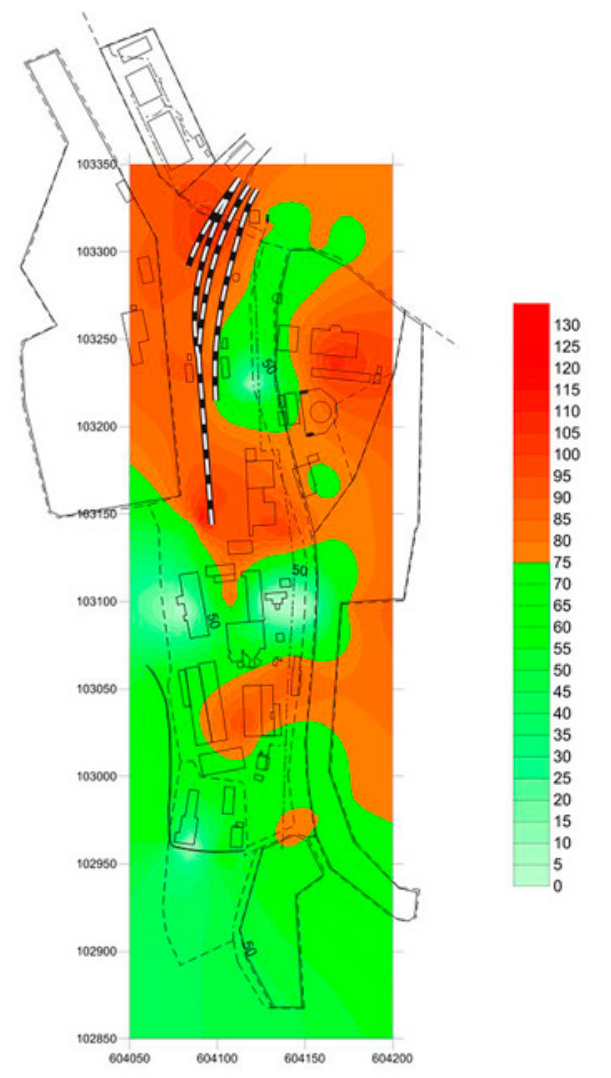

Distribution of chromium ( $\mathrm{Cr}$ ) in the topsoil (ppm)

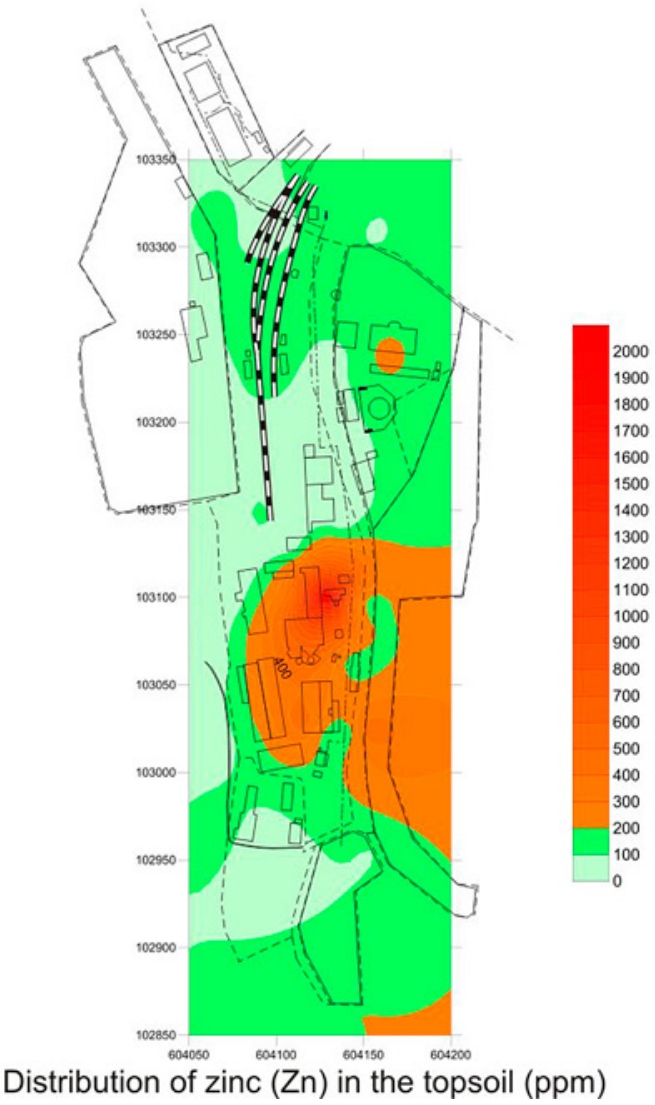

Fig. 7. TPH, $\mathrm{Cr}, \mathrm{Zn}, \mathrm{Cu}$ distribution over the surface (north direction is to the top). 
Table 3. The predicted ecological Risk Characterisation Ratio of metal in soils (EC - electrical conductivity; OM - organic matter).

\begin{tabular}{|c|c|c|c|c|c|c|c|c|}
\hline Metal & $\begin{array}{c}\text { Sample } \\
\text { code }\end{array}$ & $\begin{array}{c}\text { Back- } \\
\text { ground } \\
\left(\mathrm{mg} \mathrm{kg}^{-1}\right)\end{array}$ & $\begin{array}{c}\text { Measured } \\
\text { values } \\
\left(\mathrm{mg} \mathrm{kg}^{-1}\right)\end{array}$ & $\mathrm{pH}$ & $\mathrm{EC}(\mu \mathrm{S})$ & $\mathrm{OM}(\%)$ & Added & $\begin{array}{c}\text { Total (back- } \\
\text { ground+added) }\end{array}$ \\
\hline $\mathrm{Cu}$ & $\mathrm{B} 3$ & 20 & 170 & 7.70 & 279 & 28.12 & 1.26 & $\mathrm{RCR}$ \\
\hline $\mathrm{Zn}$ & $\mathrm{C} 3$ & 100 & 460 & 7.51 & 2100 & 87.12 & 1.33 & 1.04 \\
\hline $\mathrm{Zn}$ & $\mathrm{C} 4$ & 100 & 2090 & 7.20 & 6400 & 81.22 & 7.29 & 5.98 \\
\hline $\mathrm{Zn}$ & $\mathrm{C} 6$ & 100 & 290 & 7.48 & 390 & 5.21 & 1.21 & 1.51 \\
\hline $\mathrm{Zn}$ & Phf & 100 & 200 & 7.61 & 360 & 4.52 & 0.66 & 1.08 \\
\hline
\end{tabular}

of correction factors for the metal of interest, the differeneces betwen lab and field conditions.

The RCR value of $\mathrm{Cu}$ and $\mathrm{Zn}$ in some sample (Table 3) felt into the "high risk" category (of concern if supply volumes increase). The related box-diagram shows (Fig. 8) the results of the two sampled level. The topsoil and the deeper layers heavy metal accumulation were compared. Significant difference occurs in the case of cobalt and zinc. If the upper level dry out it is going to be exposed to wind erosion, while the particles does not cemented. The heavy metal content of the deeper levels means less or lower risk in terms of bioavailability (habitats of small mammals), because the area (soil) is highly degraded.

$\mathrm{The} \mathrm{Cu}$ is an essential element for life, however the copper poisoning can cause hemolytic anemia, diarrhea and vomiting. Also the Wilson's disease in addition to symptoms of the specific copper poisoning, associated with the liver, kidney and central nervous system disorders (Kurniawan et al 2006). Copper is an essential nutrient that is incorporated into a number of metalloenzymes involved in hemoglobin formation, drug/xenobiotic metabolism, the cross-linking of

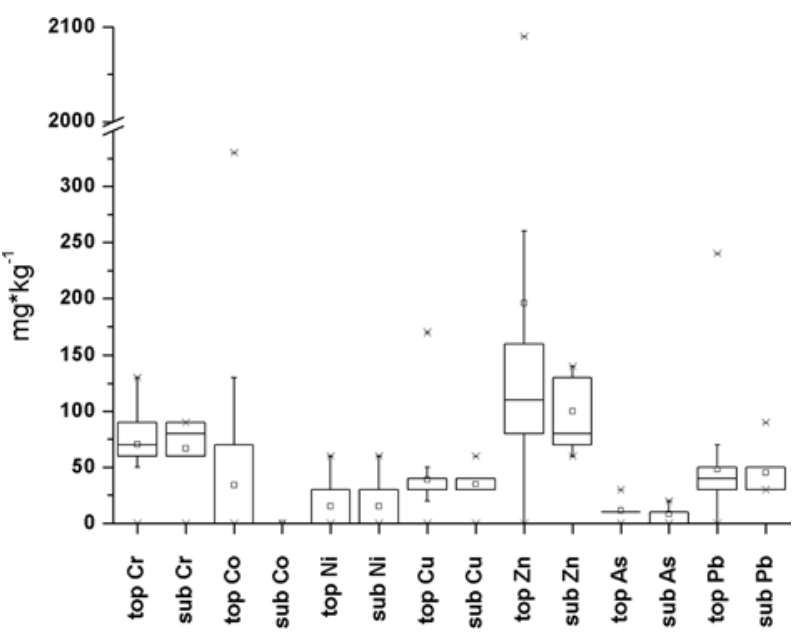

Fig. 8. Concentration of heavy metals in the subsurface and in the topsoil. collagen, elastin, and hair keratin, and the antioxidant defense mechanism (ATDSR 2015).

The Zinc also an essential element for life, and can be also overdosed. Zinc poisoning generaly cause lethargy, chills, cough, symptoms of arthritis cause pain (Vonyó 2002). Zinc is considered to be relatively nontoxic, particularly if taken orally. However, manifestations of overt toxicity symptoms (nausea, vomiting, epigastric pain, lethargy, and fatigue) will occur with extremely high zinc intakes (ASCN 1990).

\section{Identification and routing of the pollution sources}

Emission: the area of the mazout tank and pump station has a continuous pollution supply. The mazout tank is half-full with mazout, and in hot days it flows out from the tank, while all the orifices are stil open. Other places are also contaminated (Fig. 7), however we are unaware of any objects (tanks, lines, storage units, etc.) that could be the potential source of the contamination. The contamination types from those objects are mainly hidrocarbons. We have identified those ares that have been contaminated (Fig. 9) and in most case the emission is well-known. The loading area is partly rehabilitated, but one to three meters of coal dust mixed material can be found near or at the surface. This may be considered as possible emission area. Emission intensity of pollutants are highly depends on the weather condition.

Characteristic transport processes: biological availability/accessibility, groundwater leakage, overland flow, transportation and relocation of soil particles.

Direct exposure routes: direct contact with skin due to precipitation or groundwater, direct contaminant intake by dust particles due to swallowing.

Völgység stream is a potential exposure route, while the loading area is next to it, and one small 


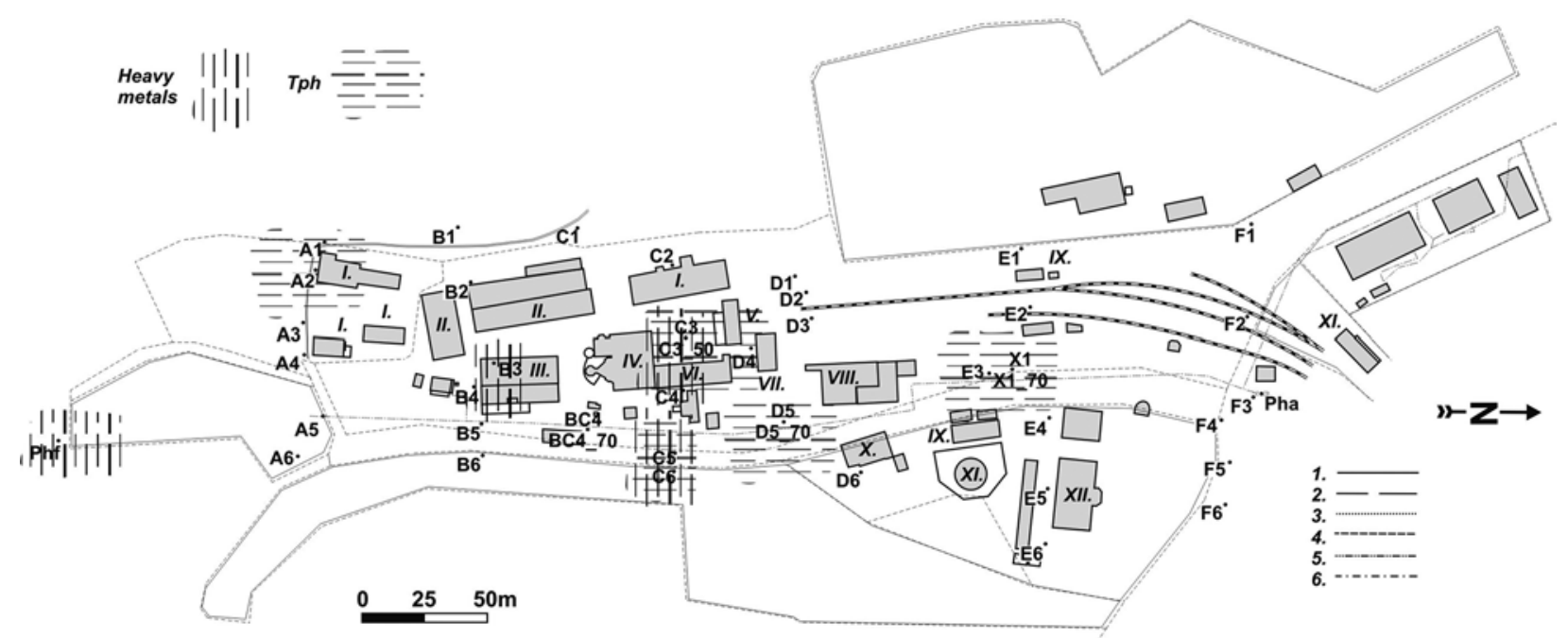

Fig. 9. The contaminated areas. Legend: I - storage units; II - fitting room; III - engine-room; IV - stokehold; V - coal-bunker; VI - dryer; VII - coal-preparatory; VIII - briquette-press; IX - pump-stations; X - transformer station; XI - bitumen tank; XII - offices; A1-F6 and Pha-Phf are sample codes.

creek flows through the abandoned industrial zone. This creek can transport a significant amount of hydrocarbon while its bed is covered by mazut. During rainy seasons or years (like 2014) the contamination can increase drastically. Our sampling was carried out during dry period, when the creek was almost dry. We measured the $\mathrm{TPH}$ on both side (inflow and outflow) of the industrial zone in accordance with the flow direction. The TPh values were five time higher at the outflow point than at the inflow point. It means that, small amount of water can carry hydrocarbons to the Völgység stream which spread it on larger area along the stream. The problem can rise under warmer condition, when the mazut start to melt and can be transported much easier then under cold condition. Thus one of the most hazardous exposure route is that small creek which also impact the so called Csalapuszta "district" along the creek. The hilly area around the former briquette factory leads the contaminant surface water flow to the Völgység stream.

Prevailing wind direction: The effect of the dusting is reduced by the prevailing SW-wind direction. However the settlement is directly bordered by the contaminated area to the NE.

Land use: well-secured, partly closed former industrial area, transit is allowed towards a vineyard district.

\section{Conclusion}

The former briquette factory of Nagymányok was heavily contaminated by TPHs and heavy metals. Highest contaminant concentrations were found around the former industrial buildings, especially between the boiler-house and the coal-pillbox.

Contamination types detected by The Raman Spectroscopy results corroborate our findings obtained by the GC-MS analytical technique. However, in some cases, significant differences were observed between the results of the two analytical techniques.

A descriptive statistical analysis of samples found that most types of pollution does not follow a normal distribution. Measured values were randomized in the study area. The reason is that the impurities that cause activity was not limited to one point. Cluster analysis was limited by the most polluted areas. These areas do not form a coherent, clustered in at least four places (engine room, dryer and central buildings, pump station, area northern part).

When we analyzed the spatial distribution of the industrial activity generated heavy metal contamination we found that horizontal differences were larger than the vertical heterogeneity of the samples. In the industrial area the mean of the detected values is below the upper limit of the legal exposure values, but among the former 
industrial buildings higher (i.e. toxic level) concentration values were detected in multiple samples. Presumably the contamination did not reach the deeper subsurface layers due to the presence of a well-developed and thick marl aquitard.

For the estimation of the volume of contaminated soils the morphological map of the area and previous technical descriptions of the industrial zone were applied.

Based on our survey, we estimated that $38 \%$ of the area is polluted by hydrocarbons $(22,500$ $\left.\mathrm{m}^{3}\right)$, down to $1.5 \mathrm{~m}$ depth, including PAH contamination in $18 \%$ (ca $10,650 \mathrm{~m}^{3}$ ). Soils heavily contaminated with heavy metals are found around buildings $\left(3.4 \%, 3,200 \mathrm{~m}^{3}\right)$. All these data point out the necessity of differentiated mitigation solutions. Heavy metal pollution calls for special technology in the future. The soils with high energy content (containing large amounts of coal powder and hydrocarbon contamination), which make up 1,400 $\mathrm{m}^{3}$, can be used as energy sources for heat generation.

\section{Acknowledgments}

Authors thanks to Nagymányok City Council for financial support and for the Raman spectroscopy supported by RK Tech Ltd. Balázs Domonkos and for Dénes Lóczy (Univ Pécs) for his useful comments.

\section{References}

ATSDR 2015. Agency for toxic Substances and Disease Registry http:// www.atsdr.cdc.gov/toxprofiles/index.asp AIST: Spectral Database for Organic Compounds, SDBS. National Institute of Advanced Indus-trial Science and
Technology (AIST) Japan. http://sdbs.db.aist.go.jp/ sdbs/cgi-bin/direct_frame_top.cgi

Dura G., 2003. Regulations related to chemical risk assessment in Hungary. Proceedings of the Workshop by the International Programme of Chemical Safety, Bulgaria, pp. 17-25.

Fonyó A., 2002. Principles of Medical Physiology. Medicina, Budapest.

Fosmire G.J., 1990. Zinc toxicity. The American Journal of Clinical Nutrition, 51(2): 225-227.

Haas J. (ed.), 1996. Magyarázó Magyarország földtani térképe a kainozoikum elhagyásával és Magyarország szerkezetföldtani térképe címú térképlapokhoz. MÁFI.

Haas J., Budai T., Csontos L., Fodor L., Konrád G., 2010. Magyarország pre-kainozoos földtani térképe 1:500,000 (Pre-Cenozoic geological map of Hungary, 1:500,000) MÁFI Geological Institute of Hungary.

Hámor G., Nagy E., Földi M., 1966. Nagymányok 1:10,000-es földtani térképsorozat. Magyar Állami Földtani Intézet.

Kurniawan T.A., Chan G.Y.S., Lo W.-h., Babel S., 2006. Comparisons of low-cost adsorbents for treating wastewaters laden with heavy metals. Science of the Total Environment, 366(2-3): 409-426.

Niton xl3t 600 Certificat Report, 2013.

Ökoproject Report (2008): MÁV Zrt Nagymányok (volt brikettgyár telephelye) Környezetvédelmi szúrővizsgálatok. Kézirat, 2008. MÁV Pécs. Ökoproject Eger Ltd.: Hungarian National Railways Close Corporation Nagymányok (former Briquette Factory) Environmental screening test. Manuscript, 2008. MÁV, Pécs.

Tarazona J.V., Vega M.M., 2002. Hazard and risk assessmenz of chemicals for terrestrial ecosystems. Toxicology, Vol. 181-182: 187-191.

Whitehouse P., Cartwright N., 1998. Standards for environmental protection. In: Douben P.E.T. (ed.), Pollution Risk Assessment and Management: A Strucutured Approach. John Wiley and Sons, Chichester, 235.

Wright K.A., Jermstad D.B., 1995. Evaluation of a Rapid Field Analytical Test Kit for Assessing Hydrocarbons Soil Contamination. Presented at the Third International Conferences On-Site Analysis. Houston.

Wright K.A. 1995. Evaluation of a New Field Test Kit for Determining Total Petroleum Hydrocarbons Concentrations in Soil at a Site Contaminated by Diesel Fuel. Presented at a Site AEHS Conference, New Orleans, LA. 